\title{
Face Shape-Based Physiognomy in LinkedIn Profiles with Cascade Classifier and K-Means Clustering
}

\author{
Purwono \\ Department of Informatics \\ Universitas Harapan Bangsa \\ Purwokerto, Indonesia \\ purwono@uhb.ac.id \\ https://orcid.org/0000-0002-7357-0405
}

\author{
Alfian Ma'arif \\ Department of Electrical Engineering \\ Universitas Ahmad Dahlan \\ Yogyakarta, Indonesia \\ https://orcid.org/0000-0002-3482-971X
}

\author{
Amanah Wulandari \\ Department of informatics \\ Universitas Harapan Bangsa \\ Purwokerto, Indonesia \\ amanahwulandari285@gmail.com
}

\begin{abstract}
The progress of a company is influenced by the excellent performance of its employee. The recruitment process should be done in a correct procedure so that it would not have the potential to harm the company. The improved use of social media can be an aspect to be applied in a recruitment process. LinkedIn is a social media platform that has many users which focuses on the career development aspect. Profile photos are commonly used in social media. In physiognomy, a personality analysis can be carried out based on his/her outward appearance. The profile photo can be an aspect of personality analysis with this knowledge. This research aimed to predict the face shape based on LinkedIn profile photos. A Cascade classifier algorithm with a haar-like feature was used to detect the face area. Dlib library was used to detect face landmarks. KMeans algorithm was used to differentiate the border of hair and facial skin. Indicators of the face shape calculation are the value of face angle, which is the arctangent of the face landmarks matrix; similarity value from the standard deviation calculation between horizontal line 1, 2, and 3; and diameter value which resulted from the standard deviation calculation between horizontal line 2 and vertical line 4 . We provide output as face shape from the LinkedIn profile photos. Based on ten profile photo samples, only two predictions were incorrect.
\end{abstract}

Keywords- Faceshape, K-Means, Cascade, Classifier, Clustering

\section{INTRODUCTION}

The progress of a company is influenced by the excellent performance of its employee. The recruitment should be done correctly to get potential candidates who can perform well in their future tasks [1]. Errors that happen in the recruitment process may cause harmful consequences for the company. Some steps in the recruitment process can still be improved with technology and social media usage [2].

Social media is interesting to be applied to improve the recruitment process [3]. This is due to the increasing number of people using various social media platforms. Social media is likely to be one of the primary needs by consuming up-todate information [4]. Different social media platforms are built for their loyal targeted users. Facebook, Twitter, Instagram, and LinkedIn are currently trending.

LinkedIn is a social media platform with many users that focuses on professionalism and career development [5]. Jobseekers or employers are gathered in one social media platform [6]. LinkedIn connects job seekers with various companies, nationally and internationally [7].

Job seekers commonly use profile photos. Profile photos are uploaded to LinkedIn in their best photo styles to give a good first impression for recruiters, then create stronger possibilities to get the job offer. In physiognomy, a person's outward appearance can represent their personality [8][9][10]. This field of study usually focuses on reading someone's character by examining their face [11]. This field of study is rapidly developing and in demand as machine learning technology advances. Profile photos that are available on social media pages can be used to predict someone's personality with improved physiognomy by using technological advances [12].

We can see that there is a possibility to use machine learning technology to predict someone's personality based on the face shape of their LinkedIn profile photos because the technology has a lot of applications [13]-[17]. The used algorithms are: Cascade Classifier to detect face landmarks, K-Means to differentiate forehead points and clustering technique that can differentiate hairline and face skin.

Generally, there are several kinds of face shape: oblong, square, diamond, oval and round [18]. The face shape will provide specific personality values in physiognomy; for example, a round face will represent cheerful, sensitive, attentive, considerate, and reliable characteristics [19]. These personality traits can be additional information in the recruitment process.

Some researches related to the use of face shape for various needs have been done. Young [20] identified someone's face shape to select a suitable frame for glasses wearers. This research applied the Viola-Jones algorithm in an Android application, which resulted in users can try various frame selections without having to wear them in reality. Meanwhile, research that has been done by Polat [21] implemented face shape with physiognomy to provide important information for plastic surgeon experts, orthodontists, and other doctors to analyze the development and structural anomalies of medical disorders. Kai [18] researched and found a relation between face shape and personality traits using a program called E-Prime.

This paper's contribution is to utilize face shape for physiognomy analysis using LinkedIn profile photos. The 
result of the physiognomy analysis will provide personality labels based on the face shape.

\section{METHODS}

Methodological steps are carried out to realize the research purpose. Overall, the research purpose of this paper is to detect someone's personality traits based on their face shape on LinkedIn profile photos. The research method includes data collection, data processing, face detection with cascade classifier, getting facial landmarks, clustering between the forehead and hairline, face shape identification, and personality analysis from physiognomy. The flow of this research can be seen in Fig. 1.

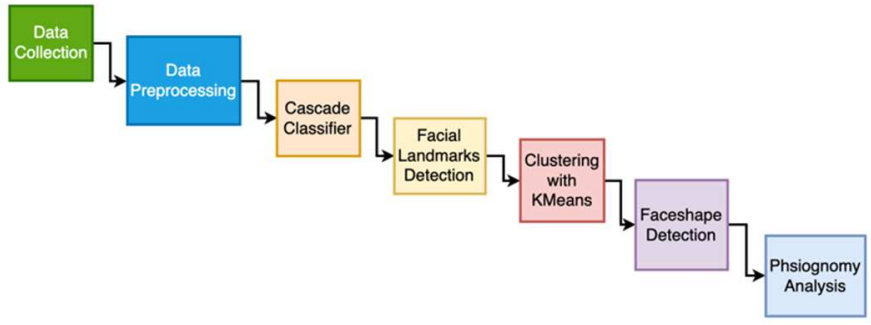

Fig. 1. Research Methods

\section{A. Data Collection \& Processing}

The data used are 20 LinkedIn profile photos of lecturers and employees of Universitas Harapan Bangsa. It consists of 10 male profile photos and 10 female profile photos. All photos have been approved for use because the authors are still at the same institution. Photos collected will be converted to gray. Gaussian blur is applied to remove high-frequency noise and to detect face shape easily.

\section{B. Cascade Classifier}

A popular Cascade Classifier algorithm was used to detect human faces [22]. This algorithm can detect histograms of skin colors, eyes, and mouths [23]. This paper used the cascade classifier to improve the face detection process and reduce computational complexity [24]. One of the features in the cascade classifier that can be used is Haar-Like [25].

Haar-like performs image classification based on simple feature values [26]. This feature is one of the methods of Viola-Jones [27]. Haar-like features are rectangular features [28], which can be given a specific indication of an image or image [29]. Features like Haar are used to identify objects based on the simple value of a feature, not pixel values contained from the image of the object [30][31]. It can be illustrated as in Fig. 2.

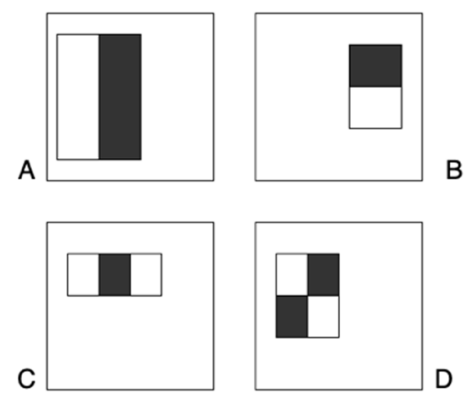

Fig. 2. Haar-Like Features in Viola-Jones

Haar-like features selection adds more Haar characteristics to get more accurate face detection [32]. Each
Haar-like feature consists of a combination of black and white rectangles [33]. The haar feature is determined by subtracting the average pixels in the dark areas from the average pixels in the bright areas [34]. If the difference value is above the threshold value, it can be said that the haar feature exists. The Haar-like feature value is the difference between the gray level pixel values contained in the black and white square areas [35]. The selection consists of (1) Edge Features, (2) Line Features, and (3) Center-Surround Features [27]. The selection process can be seen in Fig. 3.

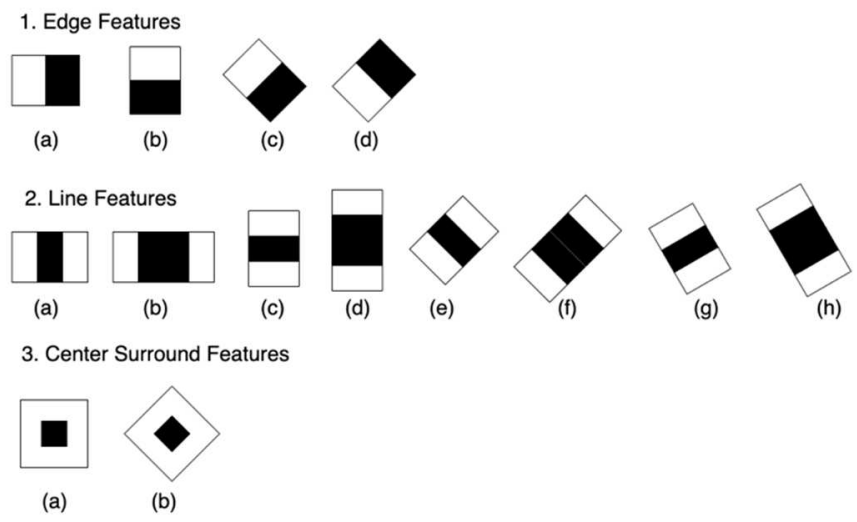

Fig. 3. Haar Features Selection

Equation (1) shows how the Haar feature selection was used.

$$
F(\text { Haar })=\sum F_{\text {white }}-\sum F_{\text {black }}
$$

Where $F($ Haar $)$ is Total characteristics value, $\sum F_{\text {white }}$ is Characteristics value in the bright area, and $\sum F_{\text {black }}$ is Characteristics value in the dark area.

\section{Facial Landmarks}

A Dlib library was used to analyze facial landmarks by extracting image values [36]. This library will result in 128dimensional feature vectors [37]. Fig. 4 illustrates the representation of facial landmarks [38].

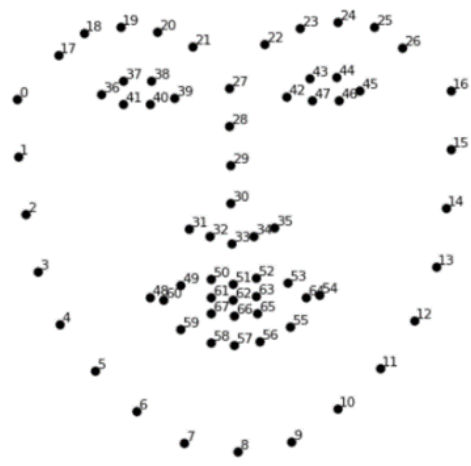

Fig. 4. Facial Landmarks

Facial landmark allocates facial points to determine the biological shape of a human face. It creates output as numbers as a facial map [39].

\section{K-Means Clustering}

After detecting the face with facial landmarks, we then group the important parts of the human face. This is done to ensure that facial landmarks enter the facial area. In other words, it is done to provide a clear boundary between the hairline and the skin of the forehead. 
To provide a clear boundary between the hairline and forehead skin, we use the K-Means Clustering algorithm, a classic distance-based algorithm [40][41]. K-Means is one of the popular algorithms used for clustering and segmentation [42][43][44]. This algorithm can be used to segment the image [45][46]. K-Means can correctly identify image pixels for decision-making [47].

The similarity between clusters was assessed based on their distance [48]. The farther the distance between two points, the smaller the similarity value. Also, a closer distance means that the clusters are considered in the same cluster group [49]. Finally, we would get all of the cluster groups. Each $i$ group of objects was divided into Kpoint groups. Then, the average of the data objects adjacent to $K$ points is calculated to be promoted to a high degree of similarity in a group [50]. Equation (2) is the calculation of group points' average score,

$$
\mu_{k}=\frac{\sum_{i=1}^{n}\left\{\left\{c^{i}=k\right\}\right\} x^{(i)}}{\sum_{i=1}^{n}\left\{c^{i}=k\right\}}
$$

where $c^{i}$ represents nearest group point in $i$ point data and $k, i=1 \ldots n$, and $\mu_{k}$ indicates the central point from group points.

The procedure to determine the cluster is (1) Getting the middle point of the forehead, (2) Detecting forehead edge that indicates hairline edge, (3) Detecting pixels' color change between forehead skin and hairline. Eventually, a clear border will be seen between the forehead skin and hair edge in the facial area. This will be adjusted so that the resulting facial landmarks enter the facial area. Facial landmarks will then be used to calculate the angle of the face using the arcus tangents.

\section{E. Face shape in Physiognomy}

This step is the implementation of physiognomy. Several indicators of personalities from face shape were used. Previously detected faces would be given horizontal and vertical lines based on their facial points. Those lines are made to ease the face shape measurement. Fig. 5 is an illustration of a face measured with the help of horizontal and vertical lines.

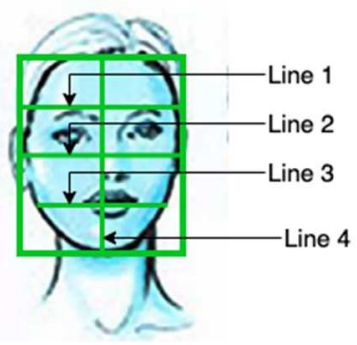

Fig. 5. Facial Outline

In physiognomy, face shape is categorized into a square, round, triangle, diamond, rectangular and oblong [18]. Face shape illustration was taken from research conducted by Kai [18]. Personality traits based on face shape [19] can be seen in Table I.

The face angle was calculated by calculating the arcus tangents from the facial landmarks that have been generated. Arcus tangent is a mathematical method that can be used to calculate the angle of a field, for example, the angle of a globe [51].
TABLE I. PERSONALITY TRAITS BASED ON FACE SHAPE

\begin{tabular}{|c|c|c|}
\hline Face shape & $\begin{array}{l}\text { Face Shape } \\
\text { Illustrations }\end{array}$ & Personality Traits \\
\hline Diamond & & $\begin{array}{l}\text { These people are intelligent and deep } \\
\text { thinkers who love to learn new things. In } \\
\text { addition, they are also known to be } \\
\text { intuitive, creative, and ambitious. } \\
\text { Unfortunately, these people tend to often } \\
\text { experience economic difficulties. }\end{array}$ \\
\hline Oblong & & $\begin{array}{l}\text { These people may have a muscular body } \\
\text { or athletic build. They are considered } \\
\text { practical, methodical and tend to be a bit } \\
\text { more workaholics. They may have a } \\
\text { troubled relationship. }\end{array}$ \\
\hline Triangle & & $\begin{array}{l}\text { This face type is usually associated with } \\
\text { a thin body and intellectual and moral } \\
\text { persuasion. They are considered creative } \\
\text { and considered to have a fiery } \\
\text { temperament, according to Chinese face } \\
\text { readers. }\end{array}$ \\
\hline Square & & $\begin{array}{l}\text { These people are considered to have } \\
\text { intelligent, analytical, and decisive } \\
\text { minds. The shape of the face is associated } \\
\text { with aggressive and domineering nature. }\end{array}$ \\
\hline Round & & $\begin{array}{l}\text { Individuals who are emotional, sensitive, } \\
\text { caring, have strong sexual fantasies, } \\
\text { usually build stable relationships. }\end{array}$ \\
\hline Rectangular & & $\begin{array}{l}\text { This person is a logical individual and a } \\
\text { strong thinker. }\end{array}$ \\
\hline
\end{tabular}

Facial landmarks data are in the form of a two-dimensional array or matrix. The first thing to do is to calculate each angle of the facial landmarks. This idea is based on research conducted by Xiang [52]. Table II contains conditions for calculating the angle of a person's face from the resulting facial landmarks data.

Facial angle was then calculated with arcus tangent that resulted in degree unit. The calculation of the angle began with saving the value of alpha0 variable that contains arcus tangents of $(c y-a y, c x-a x)$ variable, and alpha1 that contains arcus tangent of $(d y-b y, d x-b x)$ variable. The value of alpha is the difference between alpha1 and alpha0. Meanwhile, the value of angel is the result of subtraction between $180^{\circ}$ and absolute of alpha. 
TABLE II. FACE ANGLE CALCULATION

\begin{tabular}{|l|l|}
\hline Variable & \multicolumn{1}{|c|}{ Calculation } \\
\hline ax, ay & $\begin{array}{l}\text { ax = landmark point value of array index to } 1.0 \text { and ay }= \\
\text { landmark point value of array index to } 1.1\end{array}$ \\
\hline bx, by & $\begin{array}{l}\text { bx = landmark point value of array index to } 2.0 \text { and by }= \\
\text { landmark point value of array index to } 2.1\end{array}$ \\
\hline cx, cy & $\begin{array}{l}\mathrm{cx}=\text { landmark point value of array index to } 3.0 \text { and cy }= \\
\text { landmark point value of array index to } 3.1\end{array}$ \\
\hline $\mathrm{dx}, \mathrm{dy}$ & $\begin{array}{l}\mathrm{dx}=\text { landmark point value of array index to } 4.0 \text { and } \mathrm{dy}= \\
\text { landmark point value of array index to } 4.1\end{array}$ \\
\hline
\end{tabular}

The similarity of the face is the calculation of the standard deviation between horizontal line 1, horizontal 2, and horizontal 3, while the face diameter is calculated based on the standard deviation between horizontal line 2 and vertical line 4. The standard deviation can be calculated using Equation 3.

$$
\sigma=\sqrt{\frac{\sum\left(x_{i}-\mu\right)^{2}}{N}}
$$

where $\sigma$ is the population of the standard deviation, $N$ is the population size, $x_{i}$ is each value of the population, and $\mu$ is the mean of the population. The face shape detection is made based on the following conditions as in Table III [53].

TABLE III.

CONDITIONS TO DETERMINE FACE SHAPE

\begin{tabular}{|l|l|}
\hline Face shape & \multicolumn{1}{c|}{ Conditions } \\
\hline Diamond & $\begin{array}{l}\text { Face diameter is }<10 \text {. Line } 2 \text { and line } 4 \text { are similar, but } \\
\text { line } 2 \text { is slightly bigger. }\end{array}$ \\
\hline Oblong & $\begin{array}{l}\text { The length of the face is bigger, and the jawline is not } \\
\text { cornered or has no angle, which angle is }>160 \text {, and line } 4 \\
\text { is bigger than line } 2 .\end{array}$ \\
\hline Triangle & $\begin{array}{l}\text { The forehead is wider, similarity }>10, \text { and line } 2 \text { is bigger } \\
\text { than line } 1 .\end{array}$ \\
\hline Square & $\begin{array}{l}\text { The jawline is cornered, the similarity is }<10, \text { and the } \\
\text { angle is }<160 .\end{array}$ \\
\hline Round & $\begin{array}{l}\text { The jawline is not too angular where the similarity value } \\
\text { is }>10, \text { and the angle is }>160 .\end{array}$ \\
\hline Rectangular & $\begin{array}{l}\text { The length of the face is greater, and the jaw is angled } \\
\text { where line } 4 \text { is greater than line } 2, \text { and the angle is }<160 .\end{array}$ \\
\hline
\end{tabular}

\section{F. Evaluation and Personality Traits Analysis}

Analysis of personality traits was carried out after the face shape was detected from the profile photo using python programming language and the OpenCV library [54]. A detailed explanation for each type of face shape can be seen in Table 1. The samples were tested with a pre-made program, and the results were then collected and modified. The output is face shape detection from profile photos; The results are categorized into diamond, oval, triangular, square, round, or rectangular face shape types.

\section{RESULT AND DISCUSSION}

\section{A. Data Collection \& Processing}

We collected profile photos as samples from LinkedIn webpages. The number of collected samples is 10 , divided into 5 men profile photos and 5 women profile photos. The size of the photos used in this study must be square with dimensions of at least $450 \times 450$ pixels.

Pre-processing of the profile photos includes transforming them into grayscale and leveling up the Gaussian blur to reduce noise frequencies. The result of pre-processing photo can be seen in Fig. 6 .

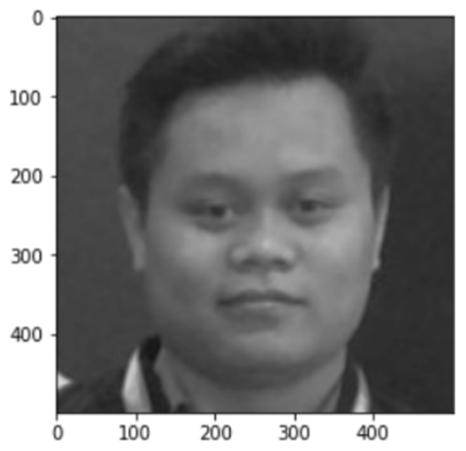

Fig. 6. Image Processing

\section{B. Cascade Classifier}

The Haar-like feature was able to detect facial areas. This method automatically outlines the detected faces with green color. Fig. 7 is the result of using a haar-like feature in the Cascade Classifier that can identify a face in an image.

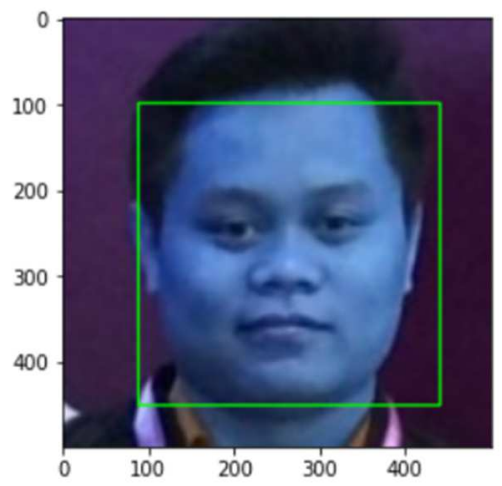

Fig. 7. Implementation of Haar-Like Feature

\section{Facial Landmarks}

The Dlib library was used to detect facial landmarks. The result is the landmark points on the detected face. The coordinate values of the points needed are then taken and processed by the system to produce a distance measurement between features in pixels [55].

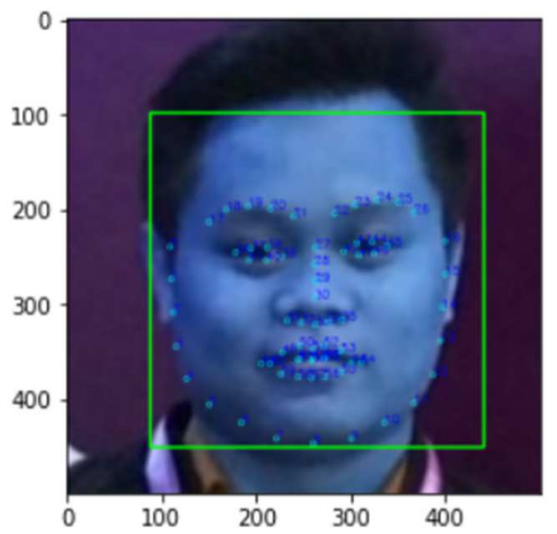

Fig. 8. Facial Landmarks with Dlib Library

Fig. 8 shows that face outlines were able to be detected properly. The facial landmarks were exactly located in the green area from the pre-processing result using cascade classifier. 


\section{K-Means Clustering}

This clustering resulted in a clear boundary between the two main groups, which are the facial skin and hair. This segmentation is used as one of the features so that facial edge measurements can be carried out properly. The result is that there is a difference in segmentation which can be seen in Fig. 9 , where the black-colored block is the facial skin area while the white-colored block is the hair area.
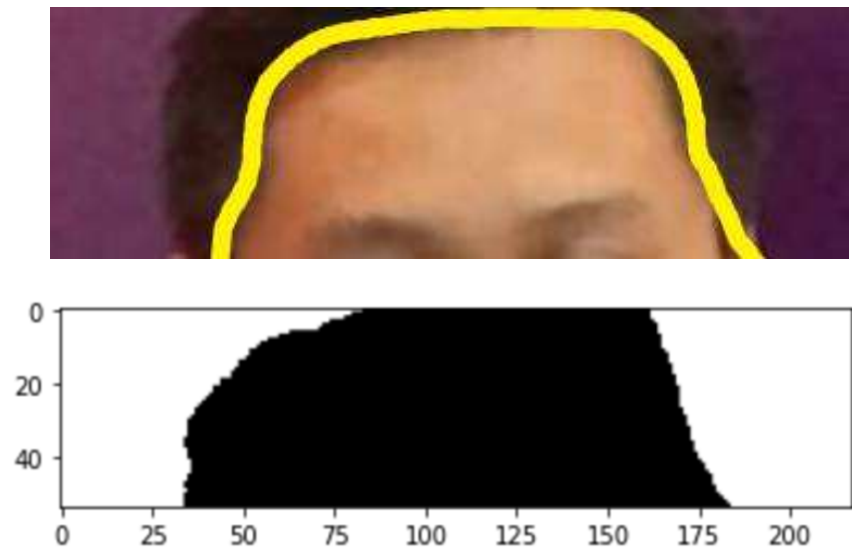

Fig. 9. Hairline and Facial Skin Cluster

\section{E. Face shape}

Vertical and horizontal lines were used to detect face shape areas. Horizontal line 1 measures the distance between the hairline and the upper facial skin. Horizontal line 2 measures the distance to the center of the face. Horizontal line 3 measures the distance of facial landmarks on the lower face. The vertical line measures the distance from the top of the hairline to the chin.

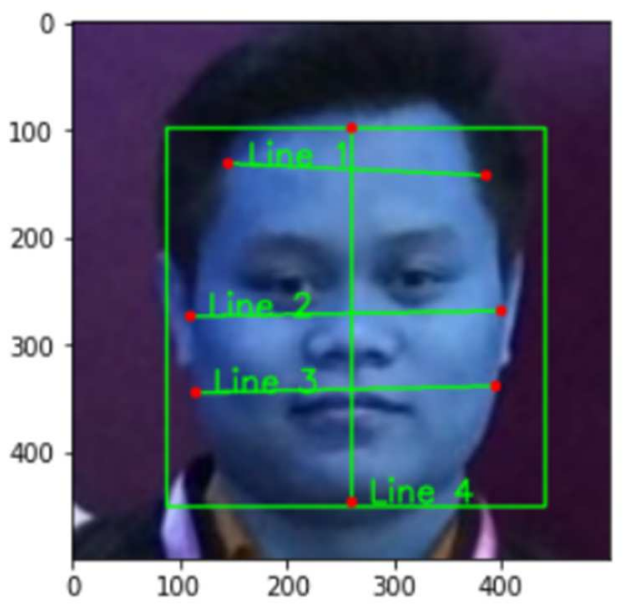

Fig. 10. Face Shape Detection with Lines

Based on Fig. 8, there are four lines that were used to detect the face shape of a person's face. The similarity value can be calculated by finding the standard deviation between line 1 , line 2 , and line 3 . Meanwhile, the face diameter is calculated by finding the standard deviation between line 2 and line 4 . In Figure 8, the similarity value is 30.739 , and the diameter is $19.5 \mathrm{~cm}$.

\section{F. Physiognomy Analysis and Evaluation}

The values of the angle, similarity, and face diameter have been collected from the previous stage. Then the facial shape analysis was carried out based on the conditions in Table III.
The evaluation was carried out on 10 samples of profile photos. The angle, similarity, and diameter of each face generated by the system are presented in Table IV.

TABLE IV. FACE SHAPE DATA VALUES

\begin{tabular}{|c|c|c|c|c|}
\hline $\begin{array}{c}\text { Profile } \\
\text { Photo }\end{array}$ & Similarity & Diameter & Angle & Face shape \\
\hline 1 & 9.53356643 & 36.0 & $\begin{array}{c}164.691642 \\
3422653\end{array}$ & Round \\
& 0716727 & & 161.873358 & Oblong \\
\hline 2 & 25.8370965 & 20.5 & 824106 & \\
\hline 3 & 10.6770782 & 45.5 & 164.267206 & Oblong \\
& 52031311 & & 38407966 & \\
\hline 4 & 12.2836838 & 45.5 & 167.905242 & Oblong \\
& 48458853 & & 9229879 & \\
\hline 5 & 23.4710223 & 35.0 & 165.245673 & Oblong \\
& 23045258 & & 35010843 & \\
\hline 6 & 20.9284495 & 33.0 & 165.247852 & Oblong \\
& 3645635 & & 2400824 & \\
\hline 7 & 29.4542960 & 32.5 & 167.031268 & Oblong \\
& 458327 & & 31248093 & \\
\hline 8 & 30.7390450 & 19.5 & 158.263987 & Triangle \\
& 22396013 & & 29450938 & \\
\hline 9 & 50.1619599 & 29.5 & 168.021371 & Oblong \\
\hline 10 & 1209098 & & 9319764 & \\
\hline & 24.2111075 & 41.0 & 168.286582 & Oblong \\
\hline & & & 79092105 & \\
\hline
\end{tabular}

As a comparison, we make predictions manually based on the user's perception of vision by looking directly at the profile photo and predicting the shape of his face. Manual prediction is made as an effort to determine whether the predictions made by the system have been made well or not. A comparison between manual prediction and face shape system prediction has been made. These results become temporary predictive parameters in the recruitment process. There are 2 predictions that do not match between manual predictions between the 10 profile photos and system predictions. The results are listed in Table V.

TABLE V. FACE SHAPE PREDICTION

\begin{tabular}{|c|c|c|c|}
\hline $\begin{array}{c}\text { Profile } \\
\text { Photo }\end{array}$ & $\begin{array}{c}\text { Manual } \\
\text { Prediction }\end{array}$ & $\begin{array}{c}\text { System's } \\
\text { Prediction }\end{array}$ & Status \\
\hline 1 & Round & Round & Matched \\
\hline 2 & $\begin{array}{c}\text { Round / } \\
\text { Triangle }\end{array}$ & Oblong & $\begin{array}{c}\text { Not } \\
\text { Matched }\end{array}$ \\
\hline 3 & Oblong & Oblong & Matched \\
\hline 4 & $\begin{array}{c}\text { Oblong / } \\
\text { Diamond }\end{array}$ & Oblong & Matched \\
\hline 5 & $\begin{array}{c}\text { Oblong / } \\
\text { Triangle }\end{array}$ & Oblong & Matched \\
\hline 7 & $\begin{array}{c}\text { Oblong } \\
\text { Round }\end{array}$ & Oblong & Matched \\
\hline 8 & $\begin{array}{c}\text { Triangle / } \\
\text { Round }\end{array}$ & Triangle & Matched \\
\hline 9 & $\begin{array}{c}\text { Oblong / } \\
\text { Diamond }\end{array}$ & Oblong & Matched \\
\hline 10 & $\begin{array}{c}\text { Oblong / } \\
\text { Diamond }\end{array}$ & Oblong & Matched \\
\hline
\end{tabular}

\section{CONCLUSIONS AND FUTURE WORK}

Based on the results, we have tried to create a system that can analyze the physiognomy of LinkedIn profile photos 
based on their face shape. The face shape calculation indicator is the face angle value, which is the calculation of the arcus tangents from the face landmarks matrix, the similarity values (standard deviation between the horizontal lines 1, 2, and 3), and the face diameter value (standard deviation of the horizontal line 2 and the vertical line 4). By calculating the face shape according to the conditions in Table III, we produced output in the form of a face shape from LinkedIn profile photos. Among 10 LinkedIn profile photos as test samples, there are 2 predictions that are not correct. Then, we can get personality traits based on a person's face shape with the science of physiognomy.

Our suggestion for further research is to improve the system that has been made with better accuracy. It is hoped that this system can be integrated with various psychological test tools for a person's personality, which is currently commonly used in the recruitment process. We also see a good opportunity to implement the system on video players within online interviews.

\section{REFERENCES}

[1] R. Umar, I. Riadi, and Purwono, "Perbandingan Metode SVM, RF dan SGD untuk Penentuan Model Klasifikasi Kinerja Programmer pada Aktivitas Media Sosial," Jurnal RESTI (Rekayasa Sistem dan Teknologi Informasi), vol. 4, no. 2, pp. 329-335, 2020.

[2] C. Tu, Z. Liu, H. Luan, and M. Sun, "PRISM: Profession identification in social media," ACM Transactions on Intelligent Systems and Technology, vol. 8, no. 6, 2017.

[3] T. Koch, C. Gerber, and J. J. De Klerk, "The impact of social media on recruitment: Are you Linkedin?," SA Journal of Human Resource Management, vol. 16, pp. 1-14, 2018.

[4] P. L. Liu, "COVID-19 information on social media and preventive behaviors: Managing the pandemic through personal responsibility," Social Science \& Medicine, vol. 277, p. 113928, May 2021.

[5] S. Candra, H. Cahyono, R. A. Wibowo, and T. Sutopo, "Acceptance of the use of social media: Case of linkedin in Indonesian netizen," International Journal of Scientific and Technology Research, vol. 9, no. 1, pp. 1451-1461, 2020.

[6] M. Cubrich et al., "Examining the criterion-related validity evidence of LinkedIn profile elements in an applied sample," Computers in Human Behavior, vol. 120, p. 106742, Jul. 2021.

[7] S. Fernandez, M. Stöcklin, L. Terrier, and S. Kim, "Using available signals on LinkedIn for personality assessment," Journal of Research in Personality, vol. 93, p. 104122, Aug. 2021.

[8] Y. Liu, M. L. Huang, W. Huang, and J. Liang, "A physiognomy based method for facial feature extraction and recognition," Journal of Visual Languages \& Computing, vol. 43, pp. 103-109, Dec. 2017.

[9] T. Zhang, R.-Z. Qin, Q.-L. Dong, W. Gao, H.-R. Xu, and Z.-Y. Hu, "Physiognomy: Personality traits prediction by learning," International Journal of Automation and Computing 2017 14:4, vol. 14, no. 4, pp. 386-395, Jun. 2017.

[10] A. Suzuki, S. Tsukamoto, and Y. Takahashi, "Faces Tell Everything in a Just and Biologically Determined World: Lay Theories Behind Face Reading," Social Psychological and Personality Science, vol. 10, no. 1, pp. 62-72, Oct. 2017.

[11] H. F. Dabbas and S. T. Muhemmed, "Effect Of Strategic Physiognomy On The Success Of Organizational Sustainability," International Journal of Advance Research and Development (Volume3, vol. 3, no. 5, 2018.
[12] W. M. K. S. Ilmini and T. G. I. Fernando, "Computational personality traits assessment: A review," 2017 IEEE International Conference on Industrial and Information Systems, ICIIS 2017 - Proceedings, vol. 2018-January, pp. 1-6, Feb. 2018.

[13] W. K. Sari, D. P. Rini, and R. F. Malik, "Text Classification Using Long Short-Term Memory With GloVe Features," Jurnal Ilmiah Teknik Elektro Komputer dan Informatika, vol. 5, no. 2, pp. 85-100, 2020.

[14] M. S. Islam, S. Sultana, and M. J. Islam, "New Hybrid Deep Learning Method to Recognize Human Action from Video," Jurnal Ilmiah Teknik Elektro Komputer dan Informatika, vol. 7, no. 2, pp. 306-313, Sep. 2021.

[15] S. Al Irfan and N. S. Widodo, "Application of Deep Learning Convolution Neural Network Method on KRSBI Humanoid RSCUAD Robot," Buletin Ilmiah Sarjana Teknik Elektro, vol. 2, no. 1, pp. $40-50,2020$.

[16] B. Y. Suprapto, A. Wahyudin, H. Hikmarika, and S. Dwijayanti, "The Detection System of Helipad for Unmanned Aerial Vehicle Landing Using YOLO Algorithm," Jurnal Ilmiah Teknik Elektro Komputer dan Informatika, vol. 7, no. 2, pp. 193-206, Jun. 2021.

[17] M. F. Maulana, S. Sa'adah, and P. E. Yunanto, "Crude Oil Price Forecasting Using Long Short-Term Memory," Jurnal Ilmiah Teknik Elektro Komputer dan Informatika, vol. 7, no. 2, pp. 286-295, Sep. 2021.

[18] Z. Kai, "The Relationship between Personality Traits and Face Shapes in Chinese Traditional Physiognomy," Open Journal of Social Sciences, vol. 09, no. 01, pp. 81-92, 2021.

[19] M. L. Abulaban, S. S. Muzher, and A. M. Thawabieh, "The Relationship between Predicting Personality Using Physiognomy and Through Using Personality Scale," World Journal of Social Science, vol. 5, no. 2, p. 22, 2018.

[20] S. Young, F. Natalia, S. Sudirman, and C. S. Ko, "Eyeglasses frame selection based on oval face shape using convolutional neural network," ICIC Express Letters, vol. 10, no. 8, pp. 707-715, 2019.

[21] S. Polat, A. G. Kabakc1, Y. Cevik, and A. H. Yucel, "The Face Shape and Golden Ratio Classification In Turkish Healthy Population," Journal of Evolution of Medical and Dental Sciences, vol. 09, no. 02, pp. 111-115, 2020.

[22] D. Kharat, P. Kajawe, S. Kopnar, N. Jinabade, and J. Wagh, "Face detection using Haar Cascade Classifier," International Journal of Innovative Research in Science, Engineering and Technology, vol. 8, no. 4, pp. 3712-3715, 2019.

[23] L. Cuimei, Q. Zhiliang, J. Nan, and W. Jianhua, "Human face detection algorithm via Haar cascade classifier combined with three additional classifiers," in 2017 13th IEEE International Conference on Electronic Measurement \& Instruments (ICEMI), 2017, pp. 483487.

[24] R. Senthamizh Selvi, D. Sivakumar, J. S. Sandhya, S. Siva Sowmiya, S. Ramya, and S. Kanaga Suba Raja, "Face Recognition Using Haar - Cascade Classifier For Criminal Identification," International Journal of Recent Technology and Engineering, vol. 7, no. 6, pp. 1871-1876, 2019.

[25] Y.-N. Lin, T.-Y. Hsieh, J.-J. Huang, C.-Y. Yang, V. R. L. Shen, and H. H. Bui, "Fast Iris localization using Haar-like features and AdaBoost algorithm," Multimedia Tools and Applications 2020 79:45, vol. 79, no. 45, pp. 34339-34362, Jun. 2020.

[26] S. O. Adeshina, H. Ibrahim, S. S. Teoh, and S. C. Hoo, "Custom Face 
Classification Model for Classroom Using Haar-Like and LBP Features with Their Performance Comparisons," Electronics 2021, Vol. 10, Page 102, vol. 10, no. 2, p. 102, Jan. 2021.

[27] Nahdi Saubari, "Deteksi Citra Wajah Dengan Metode Haar Feature Selection," Jurnal Teknologi Informasi Universitas Lambung Mangkurat (JTIULM), vol. 4, no. 1, pp. 7-12, 2019.

[28] C. Maryan, M. T. Hoque, C. Michael, E. Ioup, and M. Abdelguerfi, "Machine learning applications in detecting rip channels from images," Applied Soft Computing, vol. 78, pp. 84-93, May 2019.

[29] E. Indra et al., "Design and Implementation of Student Attendance System Based on Face Recognition by Haar-Like Features Methods," MECnIT 2020 - International Conference on Mechanical, Electronics, Computer, and Industrial Technology, pp. 336-342, Jun. 2020.

[30] S. Chau, J. Banjarnahor, D. Irfansyah, and S. Kumala, "Analisis Pendeteksian Pola Wajah Menggunakan Metode Haar-Like Feature," Journal of Informatics and Telecommunication Engineering, vol. 2, no. 2 , p. $69,2019$.

[31] V. Sanjay Kumar, S. N. Ashish, I. V. Gowtham, S. P. Ashwin Balaji, and E. Prabhu, "Smart driver assistance system using raspberry pi and sensor networks," Microprocessors and Microsystems, vol. 79, p. 103275, Nov. 2020.

[32] Z. Liu, Y. Peng, and W. Hu, "Driver fatigue detection based on deeply-learned facial expression representation," Journal of Visual Communication and Image Representation, vol. 71, p. 102723, Aug. 2020 .

[33] A. B. Shetty, Bhoomika, Deeksha, J. Rebeiro, and Ramyashree, "Facial Recognition using Haar Cascade and LBP Classifiers," Global Transitions Proceedings, Aug. 2021.

[34] M. A. Mohammed, M. K. Abd Ghani, N. Arunkumar, R. I. Hamed, M. K. Abdullah, and M. A. Burhanuddin, "A real time computer aided object detection of nasopharyngeal carcinoma using genetic algorithm and artificial neural network based on Haar feature fear," Future Generation Computer Systems, vol. 89, pp. 539-547, Dec. 2018.

[35] A. Kuchi, M. Panta, M. T. Hoque, M. Abdelguerfi, and M. C. Flanagin, "A machine learning approach to detecting cracks in levees and floodwalls," Remote Sensing Applications: Society and Environment, vol. 22, p. 100513, Apr. 2021.

[36] G. Niu and Q. Chen, "Learning an video frame-based face detection system for security fields," Journal of Visual Communication and Image Representation, pp. 457-463, 2018.

[37] Q. Chen and Lei Sang, "Face-Mask Recognition For Fraud Prevention Using Gaussian Mixture Model," Journal of Visual Communication and Image Representation, pp. 795-801, 2018.

[38] A. D. Purwanto and F. Utaminingrum, "Deteksi Pergerakan Mata dan Kedipan Untuk Memilih Empat Menu Display Menggunakan Probabilitas Berdasarkan Facial Landmark," Jurnal Pengembangan Teknologi Informasi dan Ilmu Komputer, vol. 3, no. 11, pp. 10865 10874, 2019.

[39] S. Han, Z. Yang, Q. Li, and Y. Chen, "Deformed Landmark Fitting For Sequential Faces," Journal of Visual Communication and Image Representation, pp. 381-393, 2019.

[40] B. Wu, "K-means clustering algorithm and Python implementation,"
2021 IEEE International Conference on Computer Science, Artificial Intelligence and Electronic Engineering (CSAIEE), pp. 55-59, Aug. 2021.

[41] M. Ahmed, R. Seraj, and S. M. S. Islam, "The k-means Algorithm: A Comprehensive Survey and Performance Evaluation," Electronics 2020, Vol. 9, Page 1295, vol. 9, no. 8, p. 1295, Aug. 2020.

[42] I. Ihsan, E. W. Hidayat, and A. Rahmatulloh, "Identification of Bacterial Leaf Blight and Brown Spot Disease In Rice Plants With Image Processing Approach," Jurnal Ilmiah Teknik Elektro Komputer dan Informatika, vol. 5, no. 2, pp. 59-67, 2020.

[43] H. Zhang and Q. Peng, "PSO and K-means-based semantic segmentation toward agricultural products," Future Generation Computer Systems, vol. 126, pp. 82-87, Jan. 2022.

[44] K. Deeparani and P. Sudhakar, "Efficient image segmentation and implementation of K-means clustering," Materials Today: Proceedings, vol. 45, pp. 8076-8079, Jan. 2021.

[45] S. Basar, M. Ali, G. Ochoa-Ruiz, M. Zareei, A. Waheed, and A. Adnan, "Unsupervised color image segmentation: A case of RGB histogram based K-means clustering initialization," PLOS ONE, vol. 15, no. 10, p. e0240015, Oct. 2020.

[46] M. K. Islam, M. S. Ali, M. S. Miah, M. M. Rahman, M. S. Alam, and M. A. Hossain, "Brain tumor detection in MR image using superpixels, principal component analysis and template based $\mathrm{K}$ means clustering algorithm," Machine Learning with Applications, vol. 5, p. 100044 , Sep. 2021.

[47] U. J. F. Ufrima, "Image segmentation using K-means," International Journal of Advanced Science and Technology, vol. 29, no. 6, pp. 3700-3704, 2020.

[48] A. Młodak, "k-Means, Ward and Probabilistic Distance-Based Clustering Methods with Contiguity Constraint," Journal of Classification 2020 38:2, vol. 38, no. 2, pp. 313-352, Aug. 2020.

[49] J. Eliyanto and S. Surono, "Distance Functions Study in Fuzzy CMeans Core and Reduct Clustering," Jurnal Ilmiah Teknik Elektro Komputer dan Informatika, vol. 7, no. 1, pp. 118-130, Apr. 2021.

[50] P. Wei, Z. Zhou, L. Li, and J. Jiang, "Research On Face Feature Extraction Based On K-Mean Algorithm," Eurasip Journal on Image and Video Processing, vol. 2018, no. 1, 2018.

[51] S. Bektas, "Direct bearing angles determination on globe," MOJ Civil Engineering, vol. 5, no. 4, pp. 78-80, 2019.

[52] X. Li, J. Liu, J. Baron, K. Luu, and E. Patterson, "Evaluating effects of focal length and viewing angle in a comparison of recent face landmark and alignment methods," Eurasip Journal on Image and Video Processing, vol. 2021, no. 1, 2021.

[53] S. Rajapaksha and B. Kumara, "Hairstyle Recommendation Based on Face Shape Using Image Processing," in 11Th International Research Conference, 2018, no. January, pp. 1-3.

[54] Z. Zhu and Y. Cheng, "Application of attitude tracking algorithm for face recognition based on OpenCV in the intelligent door lock," Computer Communications, vol. 154, pp. 390-397, Mar. 2020.

[55] U. D. Rosiani et al., "Penerapan Facial Landmark Point Untuk Klasifikasi Jenis Kelamin Berdasarkan CItra Wajah,” JIP (Jurnal Informatika Polinema, vol. 6, no. 1, pp. 55-60, 2019. 